\title{
Mechanisms of HBx Mediated Liver Cancer: Multiple Pathways and Opportunities
}

\author{
Mark A. Feitelson et al. \\ Department of Biology, Temple University, Philadelphia, PA
}

USA

\section{Introduction}

Chronic hepatitis B virus (HBV) infection is associated with a high risk for the development of chronic liver diseases (CLDs) which include hepatitis, cirrhosis and hepatocellular carcinoma (HCC). HCC is among the top five most prevalent tumor types worldwide, has few effective treatment options, and is highly lethal. The pathogenesis of CLD and HCC is immune mediated, and the virus has developed a number of defense mechanisms that essentially prevent infected cells from being effectively eliminated by the immune system. This, in part, involves the sustained, high level expression of the virus encoded protein, hepatitis $\mathrm{B} x$ antigen $(\mathrm{HBx})$. Recent work has shown that $\mathrm{HBx}$ blocks pathways of innate immunity (Kumar et al., 2011; Wei et al., 2010), thereby blunting the development of adaptive immunity that is central to virus elimination. In addition, HBx inhibits immune mediated apoptosis by multiple pathways, including those mediated by Fas and tumor necrosis factor alpha (TNF $\alpha)$. In this context, $\mathrm{HBx}$ has been shown to up-regulate $\mathrm{TNF} \alpha$ expression (Lara-Pezzi et al., 1998), which is thought to kill uninfected hepatocytes more readily than infected cells, thereby promoting expansion of the virus within the liver, since virus infected hepatocytes would preferentially regenerate following a bout of chronic hepatitis. HBx also switches the growth signals mediated by elevated transforming growth factor beta 1 (TGF $\beta 1$ ) from that of negative growth regulation to that of positive growth regulation. TGF $\beta 1$ is a transcriptional target of $\mathrm{HBx}$ (Yoo et al., 1996), suggesting that $\mathrm{HBx}$ expression in the liver promotes fibrogenesis and the development of cirrhosis. Within the infected hepatocyte, HBx blocks the action of tumor suppressors, such as p53 and $\mathrm{Rb}$ (Feitelson et al., 2008), and up-regulates the expression of selected host genes that strongly promote hepatocarcinogenesis even in the absence of $\mathrm{HBx}$ (see below). Recent work has also

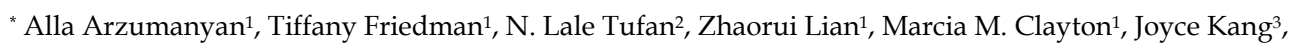
Helena M. G. P. V. Reis ${ }^{4}$, Jingbo Pan', Jie Liu', Patrick Arbuthnot ${ }^{7}$ and Michael Kew ${ }^{7}$

${ }^{1}$ Department of Biology, Temple University, Philadelphia, PA, USA

${ }^{2}$ Department of Medical Biology, Pamukkale University School of Medicine, Kinikli Denizli, Turkey

${ }^{3}$ Division of Medical Microbiology, Guiyang Medical College, Guizhou Province, People's Republic of China

${ }^{4}$ MIT Portugal Program, Av. Antonio Jose de Almeida, Lisboa, Portugal

${ }^{5}$ Department of Pathology, Anatomy and Cell Biology, Thomas Jefferson University, Philadelphia, PA, USA

${ }^{6}$ Department of Digestive Diseases of Huashan Hospital, Fudan University, Shanghai, P. R. China

${ }^{7}$ Molecular Hepatology Research Unit, Department of Medicine, University of the Witwatersrand, Johannesburg,

South Africa
} 
shown that HBx promotes phenotypic changes in hepatocytes characteristic of epithelial-tomesenchymal transition (EMT). One of the molecular hallmarks of EMT, down-regulated expression of the cell adhesion molecule, E-cadherin, is blocked by sustained HBx expression via several mechanisms (Feitelson et al., 2009). HBx also overrides immune mediated apoptotic signals by constitutively activating key signaling pathways, such as nuclear factor kappa B (NF-kB), which is known to be hepatoprotective (Beg et al., 1995, 1996), and phosphatidylinositol 3-kinase (PI3K)/Akt, which is known to promote growth in many tumor types (Chung et al., 2004). The finding that HBx stabilizes $\beta$-catenin by a variety of mechanisms, and up-regulates ErbB2 (Liu et al., 2009), further underscores the importance of these actions in maintaining hepatocellular growth and survival required for virus propagation during the many years and decades that span chronic infection. Unfortunately, these same pathways are also those that contribute centrally to the development of HCC. This body of work provides many opportunities for the development of diagnostic markers that form a fingerprint of those chronically infected patients who are most likely to go on and develop HCC. These markers will serve as therapeutic targets for the repositioning of known drugs for this new indication, and/or the discovery of new drugs that will target rate limiting pathways during multi-step carcinogenesis. In doing so, this work proposes that the chemoprevention of cancer, instead of the treatment of tumor bearing patients, is worth pursuing, and could likely reduce or eliminate the morbidity and mortality associated with chronic HBV infection long before tumors appear. This represents an important challenge, since the knowledge gained will identify cause and effect relationships important for the identification of definitive biomarkers and pharmacological targets that participate decisively in tumorigenesis.

\section{Relationship between HBx expression and the pathogenesis of CLD and (HCC): A model}

$\mathrm{HBx}$ is one of four genes expressed by HBV during infection, and is known to have gene regulatory functions. Truncated envelope polypeptides that appear during chronic infection may also regulate gene expression and contribute to the pathogenesis of CLD and liver cancer (Chen et al., 2006; Lauer et al., 1992), but their contributions are less well characterized. HBx has been defined as a trans-activating protein that promotes virus gene expression and replication during infection (Belloni et al., 2009; Spandau \& Lee, 1988; Tsuge et al., 2010). Experimental infection of newborn woodchucks with the related woodchuck hepatitis virus (WHV) results in the development of carriers in nearly $100 \%$ of cases, and most of these go on to develop severe chronic hepatitis and HCC (Tennant \& Gerin, 2001). However, infection of neonatal woodchucks with an X protein negative clone of WHV failed to establish the chronic carrier state (Chen et al., 1993; Zoulim et al., 1994). This suggests that $X$ protein promotes viremia. The impact of $X$ protein on virus gene expression and replication is also supported by considerable in vitro data (Benhenda et al., 2009; Keasler et al., 2009; Tsuge et al., 2010). During the course of CLD, bouts of hepatitis are associated with hepatocellular destruction and regeneration. Among infected cells, the $X$ open reading frame (ORF), which is at the end of the virus genome, becomes repeatedly integrated into host DNA at the replication forks that exist in host DNA during regeneration. This suggests that the intracellular levels of $\mathrm{HBx}$ increase with the severity and progression of CLD, and there is now considerable experimental evidence to support this hypothesis (Feitelson et al., 1993a; Jin et al, 2001; Wang et al., 1991a, 1991b). In fact, the highest levels of HBx expression 
have been observed in cirrhotic nodules (Wang et al., 1991a, 1991b). As indicated above, $\mathrm{HBx}$ trans-activates HBV enhancers and promoters, thereby promoting long term virus replication. However, it is proposed that when the levels of intracellular HBx increase with time among patients with CLD, it trans-regulates the expression of many cellular genes as well (Balsano et al., 1994; Twu \& Schloemer, 1987) by a variety of mechanisms. It is postulated that these changes in cellular gene expression help to make cells more permissive to continued virus replication, but also protect the cells from immune responses aimed at removal of infected hepatocytes. This is accomplished by triggering EMT (Du et al., 2010; Yang et al., 2009), by promoting up-regulated expression of selected oncogene associated pathways, and by turning off tumor suppressor, senescence and apoptotic pathways (Kew, 2011; Oishi et al., 2007; Park et al., 2011; Xu et al., 2010) that are often activated by immune responses against virus infected cells. The fact that HBx promotes cell cycle progression and cell growth (Feitelson et al., 2005), means that when this happens in normal hepatocytes, negative growth regulatory (senescence and tumor suppressor) pathways are triggered to reestablish homeostasis. The latter may underlie the putative "proapoptotic" properties of $\mathrm{HBx}$ observed in cell lines and in vivo, even though there is a considerable literature showing that HBx is also "anti-apoptotic" (Assrir et al., 2010). In this model, it is proposed that apoptosis is a cellular response to inappropriate growth stimulatory signals in the liver mediated by HBx during chronic infection and not due to an inherent property of $\mathrm{HBx}$. Although there is considerable literature suggesting that $\mathrm{HBx}$ inhibits several DNA repair systems (e.g., Cheng et al., 2010; Martin-Lluesma et al., 2008; Mathonnet et al., 2004; Qadri et al, 2011), which would promote the development of mutations in the liver prior to the appearance of tumors, it appears that a major contribution of $\mathrm{HBx}$ to the pathogenesis of CLD is epigenetic. This is because many natural effectors of HBx correlate with $\mathrm{HBx}$ expression in chronically infected human livers and because mutations are not widespread in preneoplastic hepatocytes (Feitelson et al., 2002). The finding that HBx and its natural effectors (target genes) correlate in nontumor liver, but are mostly absent from adjacent tumor tissues, suggests that $\mathrm{HBx}$ and its target genes drive pathogenesis prior to the appearance of tumor, but are no longer rate limiting once tumors appear. In the latter case, it is proposed that epigenetic mechanisms mediated by $\mathrm{HBx}$ are replaced by genetic mechanisms that are independent of $\mathrm{HBx}$. If so, then $\mathrm{HBx}$ may play a predominant role in the pathogenesis of CLD, but a more modest role in tumor progression.

\section{Natural targets of HBx}

Early work characterized HBx as a trans-regulatory protein that was initially shown to upregulate the expression of almost every target gene that was evaluated using mostly reporter gene assays in transient transfected cell lines (Rossner, 1992). It seemed that in order to better understand what $\mathrm{HBx}$ was doing in vivo, the natural effectors and targets of $\mathrm{HBx}$ in the infected liver had to be identified and characterized. HBx targets that were up- or downregulated were identified by microarray analysis, miRNA arrays, chromatin immunoprecipitation, and by other techniques (e.g., Hu et al., 2006; Sung et al., 2009; Wu et al., 2001, 2002). Some of the targets include telomerase (Liu et al, 2010), the ras pathway signaling molecule, RASSF1A (Yang, et al, 2010), the metastasis associated protein, MTA (Bui-Nguyen et al, 2010), $\beta$-catenin (Lian et al., 2006; Pan et al., 2007), E-cadherin (Liu et al., 2006), c-myc (Wu et al., 2001), and DNA methyltransferase 1 (Zheng et al., 2009). HBx is a protein binding protein that also regulates gene expression by activating a number of signal 
transduction pathways in the cytoplasm (e.g., NF-кB, PI3K/Akt, JAK/STAT, PKC, AP-1, ras, src, Wnt and others) (Feitelson \& Duan, 1997; Henkler \& Koshy, 1996; Kew, 2011). Constitutive activation of these signaling pathways has been identified with up-regulated expression of specific target genes. For example, HBx mediated activation of the mitogenactivated protein kinase (MAPK) pathway has been shown to up-regulate the expression of hypoxia-inducible factor- 1 alpha (HIF-1 $\alpha$ ) (Yoo et al., 2003), which promotes the survival of hepatocytes in cirrhotic nodules, where a hypoxic environment is known to exist during CLD. Further, HBx mediated constitutive activation of Wnt signaling is associated with upregulated expression of c-myc and cyclin-D1, both of which promote hepatocellular growth. In the nucleus, HBx interacts with the basal transcription machinery (Haviv, et al., 1995, 1996), binds to the transcriptional scaffolds CBP/p300 (Cougot et al., 2007) and mSin3a (Arzumanyan et al., 2011), and alters the extent of DNA methylation and histone acetylation (Zheng et al., 2009). Further, there is increasing evidence that HBx alters the expression of host gene expression by up- or down-regulating selected miRNAs (Kong et al., 2011; Wu, et al., 2011). In many cases, the natural targets of these epigenetic changes have not been identified. The importance of doing so will provide both prognostic markers and therapeutic targets relevant to the pathogenesis of CLD and HCC, thus providing opportunities for earlier intervention.

\subsection{HBx and fibrogenesis}

\subsubsection{Transforming growth factor beta 1 (TGF $\beta 1$ )}

The close association between intrahepatic expression of $\mathrm{HBx}$ and the severity of CLD suggests that HBx may take a part in driving pathogenesis. TGF $\beta 1$ is an important mediator of fibrosis and apoptosis in carriers with CLD (Castilla et al., 1991; Liu et al., 1999), as indicated by the direct correlation between serum TGF $\beta 1$ levels, elevated aminotransferases, and fibrosis scored in liver biopsy specimens (Flisiak et al., 2004). HBx has been shown to transcriptionally up-regulate the expression of TGF $\beta 1$ both in cell cultures and in HBx transgenic mice (Martin-Vilchez et al., 2008; Norton et al., 2004; Yoo et al., 1996). In liver tissue with HBx protein expression, phospho-Smad2 was detectable, suggesting a functional link between viral protein expression and TGF- $\beta 1$ signaling. Phospho-Smad 2 staining correlated significantly with fibrotic stage in patients with $\mathrm{HBV}$ infection and steatosis/steatohepatitis (Weng et al., 2009). HBx mediated up-regulation of TGF $\beta 1$ was further potentiated by suppressed expression of the natural inhibitor of TGF $\beta 1$, alpha-2macroglobulin ( $\alpha 2 \mathrm{M}$, Figure 1) (Pan et al., 2004). HBx may suppress $\alpha 2 \mathrm{M}$ gene expression by either activation of NF- $\kappa \mathrm{B}$, which then blocks the activation of the $\alpha 2 \mathrm{M}$ gene by STAT3, and/or by the $\mathrm{HBx}$ activation of PI3K, which then blocks $\alpha 2 \mathrm{M}$ expression. Independent work showed that HBx also shifted TGF $\beta 1$ signaling from tumor suppression to tumor promotion in the livers of patients with chronic hepatitis B, and that this involved differential phosphorylation of smad3 in vivo (Murata et al., 2009). HBx was also shown to enhance TGF $\beta$ signaling by stabilizing a protein complex consisting of smad4 and components of the basic transcriptional machinery (Lee et al., 2001). The fact that HBx stimulates multiple signal transduction pathways (e.g., NF- $\mathrm{B}, \mathrm{PI} 3 \mathrm{~K}, \mathrm{MAPK}, \mathrm{Wnt}$, ras, src, etc), combined with altered smad signaling, also appear to override the homeostatic and growth inhibitory properties of TGF $\beta 1$. This results in the development of a strong profibrogenic environment in the liver (Akhurst, 2002) which may underlie the close 
relationship between $\mathrm{HBx}$, inflammation, and fibrogenesis seen in earlier studies (Wang et al., 1991a, 1991b). In this context, hepatic inflammation, fibrosis and cell death were demonstrated in TGF $\beta 1$ transgenic mice (Sanderson et al., 1995), underscoring the contribution of elevated TGF $\beta 1$ expression to CLD. Interestingly, HBx also blocks TGF $\beta 1$ mediated growth inhibition and apoptosis, in part, through the up-regulation of PI3K (Shih et al., 2000), suggesting that HBx may confer resistance to TGF $\beta 1$ mediated growth inhibition, while uninfected cells remain sensitive, thereby favoring survival of virus infected hepatocytes. These observations are consistent with the strong correlation between $\mathrm{HBx}$ staining and the progression of CLD among HBV infected carriers (Jin et al, 2001; Wang et al., 1991a, 1991b).

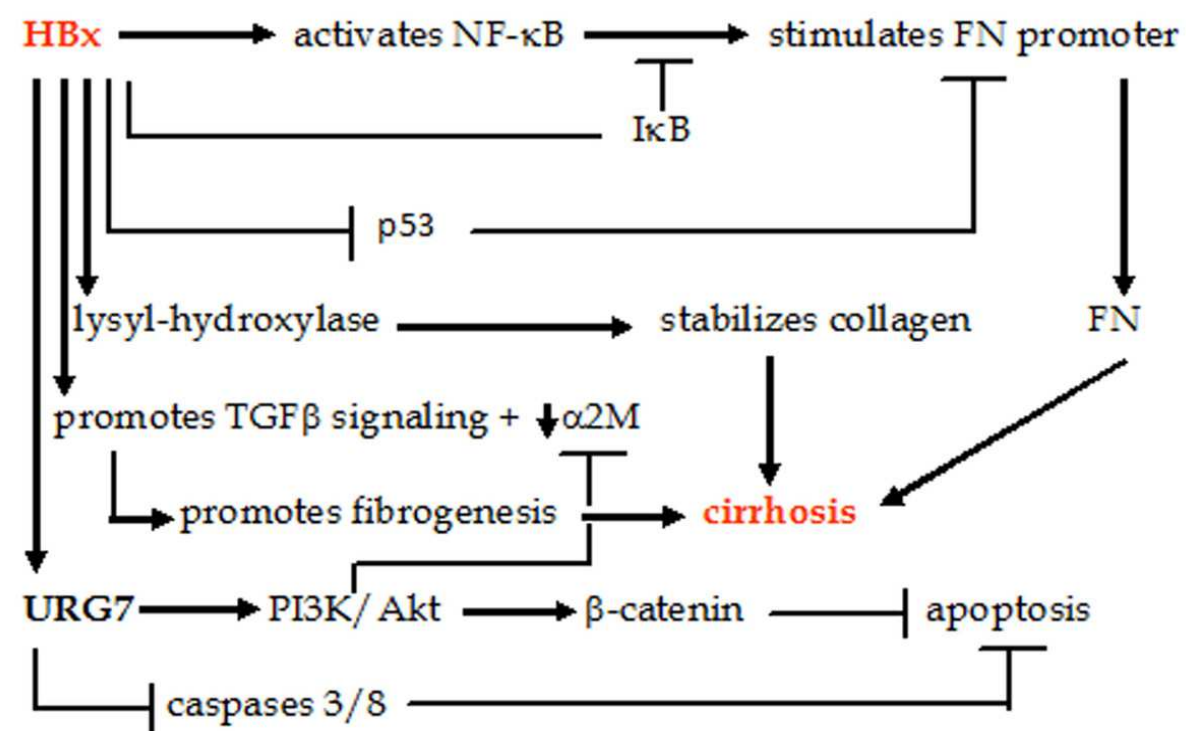

Fig. 1. Proposed model of how HBx may contribute to the development of cirrhosis. See the text for details.

\subsubsection{Fibronectin (FN)}

This close relationship is exemplified by the observations that HBx activation of NF- $\kappa B$ resulted in the stimulation of the fibronectin (FN) promoter (Figure 1), and that liver tissue samples from chronically infected patients showed a strong correlation between HBx and FN mRNA in hepatocytes from fibrotic and cirrhotic livers (Norton et al., 2004). In this context, the fact that HBx binds to and inactivates the tumor suppressor protein, p53, both in vitro and in vivo (Feitelson et al., 1993b; Ueda et al., 1995), and that p53 normally suppresses the FN promoter, suggest that inactivation of p53 also results in increased FN production. Interestingly, up-regulation of FN in HBx expressing cells also showed a modest (50\%) decrease in adherence to FN (Lara-Pezzi et al., 2001a, 2001b) and depressed expression of the FN receptor, $\alpha 5 \beta 1$ integrin. There was also an observed decrease in the levels of collagen/laminin receptor $\alpha 1$ subunit in $\mathrm{HBx}$ positive compared to negative cells 
(Lara-Pezzi et al., 2001a), suggesting that HBx promotes the detachment of infected cells from the extracellular matrix (ECM). This detachment was associated with increased cell migration, indicating that changes in the ECM-cell relationship probably also contributed to alterations in tissue morphology that accompany the development of cirrhosis. Since activated ras and src signaling depress $\alpha 5 \beta 1$ expression (Varner et al., 1995), that HBx stimulates ras and src signaling (Klein \& Schneider, 1997), and that HBx disrupts adherens junctions in a src dependent manner (Lara-Pezzi et al., 2001b), it is likely that the activation of these signaling pathways by $\mathrm{HBx}$ contribute importantly to decreased integrin expression, decreased cell adhesion, and an increased propensity for cell migration and loss of tissue morphology in the infected liver, and to metastasis in already established tumors.

\subsubsection{Lysyl hydroxylase (LH3)}

As indicated above, the accumulation and remodeling of ECM is central to the development of fibrosis and cirrhosis. In this context, the finding that HBx up-regulates the expression of the enzyme, lysyl hydroxylase 3 (LH3) in liver cells, and that LH3 co-stains with HBx in livers of HBV infected patients (unpublished observations), suggests another mechanism whereby an HBx target gene may contribute to fibrosis (Figure 1). LH3 mediates the chemical cross-linking of several collagen and collagen-like molecules (Myullyla et al., 2007). This may promote stabilization of the ECM during chronic infection. Given that LH3 knockout mice with disrupted formation of basement membranes during embryogenesis resulted in embryonic lethality (Myullyla et al., 2007), the over-expression of LH3 during chronic HBV infection may promote the development and persistence of basement membranes that are characteristic of fibrosis. This would sever the intimate relationship between hepatocytes and the bloodstream observed in normal livers. Although LH3 is associated with the endoplasmic reticulum, it has also been found in the extracellular space and in serum (Salo et al., 2006), implying that LH3 serum levels may be elevated in the blood prior to the development of HCC.

\subsubsection{Does HBx activate stellate cells?}

It is also possible that $\mathrm{HBx}$ expression promotes stellate cell activation. Although there is little evidence that HBV infects stellate cells, when HBx was transfected into a human stellate cell line, it promoted proliferation and up-regulated expression of fibrosis related molecules (Guo et al., 2009). Independent work showed that HBx expressing hepatocytes induced paracrine activation of human and rat hepatic stellate cells. When these cells were exposed to conditioned medium from HBx-expressing hepatocytes, they showed increased expression of collagen I, connective tissue growth factor, alpha smooth muscle actin, matrix metalloproteinase-2, and TGF $\beta$, together with an enhanced proliferation rate (MartinVilchez et al., 2008). More recently, hedgehog signaling and ligand production have been demonstrated to be activated in clinical samples from HBV (and hepatitis C virus) infected patients These ligands promoted the in vitro expansion of liver myofibroblasts, activated endothelial cells, and progenitors expressing markers of tumor stem/initiating cells (Pereira et al., 2010). Independent data has shown that hedgehog signaling is profibrogenic, in that it promotes activation and EMT in quiescent hepatic stellate cells (Choi et al., 2009), and in the context of cholestatic liver injury (Omenetti et al., 2011). Given that hedgehog signaling is 
also known to promote tissue remodeling in the liver (Omenetti \& Diehl, 2008), it is possible that this may contribute to the progression and formation of cirrhotic nodules in the liver of chronically infected patients. Preliminary data also suggests that HBx activates hedgehog signaling in liver cancer cells (Kim et al., 2011), although the role of this activation in hepatocarcinogenesis remains to be studied. Further, it is not clear whether the upregulation of hedgehog ligands is activated by $\mathrm{HBx}$, and whether this in some way contributes to fibrogenesis.

\subsection{HBx up-regulated genes in chronically infected liver}

\subsubsection{Up-regulated gene, clone 7 (URG7)}

Subtractive hybridization of mRNAs from HBx positive compared to negative human hepatoblastoma (HepG2) cells yielded a set of differentially expressed mRNAs that revealed additional mechanisms whereby $\mathrm{HBx}$ contributes to the pathogenesis of HCC. Several unique mRNAs were identified by subtractive hybridization, and among them were a number of previously uncharacterized transcripts. One of them, URG7, encoded a 99 amino acid polypeptide with no distinguishing functional motifs (Lian et al., 2001), was found to down-regulate the expression of the TGF $\beta 1$ inhibitor, $\alpha 2 \mathrm{M}$ (Figure 1), suggesting that it contributes to the development and progression of fibrosis. It appears to do so by activation of PI3K, by stabilization of $\beta$-catenin, and by blocking the activities of caspase 8 and 3 (Pan et al., 2007) (Figures 1 and 2). Among its many activities, HBx also activates PI3K (Lee et al., 2001), stabilizes $\beta$-catenin (Lian et al., 2006), and blocks caspase 3 (Gottlob et al., 1998), suggesting that these functions may be carried out by URG7. Further data showed that both HBx and URG7 activated fragments of the $\beta$-catenin promoter, and also promoted expression of $\beta$-catenin target genes. These include c-myc (Terradillos et al., 1997), multidrug resistance gene 1 (MDR1) (Doong et al., 1998) and cyclin D1 (Park et al., 2006). While the activation of $\beta$-catenin target genes by URG7 suggests that the latter promotes tumor formation, URG7 did not promote growth of HepG2 cells in soft agar, nor did it accelerate the outgrowth of HepG2 based tumors in SCID mice (Lian et al., 2001). Its role in blocking apoptosis, however, is shared with that of $\beta$-catenin (Chen et al., 2001). Importantly, one of the major characteristics of tumor cells is resistance to immune mediated apoptosis. The finding that URG7 is over-expressed in infected liver, but not in HCC cells from clinical specimens, suggests that resistance to apoptosis precedes the development of tumor, and that it probably protects HBV infected cells from immune damage and elimination. On the molecular level, caspase 8 , which is just up-stream of caspase 3, transmits death signals from Fas (T cell) and from TNF $\alpha$ signaling (Figure 2). In this context, it had previously been shown that HBx blocks Fas mediated killing in primary human hepatocytes (Diao et al., 2001), which may actually be mediated by URG7. Further, the finding that HBx

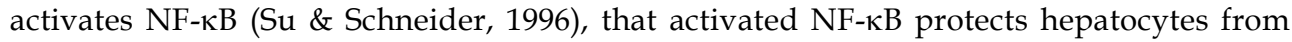
cell death (Beg et al., 1995, 1996), and that NF-кB transcriptionally activates URG7 (Pan et al., 2001), suggest a pathway that promotes persistence of the carrier state (and sustained HBV replication) even in the presence of recurring immune responses spanning many years. The findings of elevated $\mathrm{TNF} \alpha$ production in human hepatocytes infected with $\mathrm{HBV}$, and that HBx targets this up-regulation (Lara-Pezzi et al, 1998), not only suggests that $\mathrm{TNF} \alpha$ is a target for $\mathrm{HBx}$, but is also consistent with the strong correlation between HBx expression and inflammatory liver disease (Jin et al., 2001; Wang et al., 1991a, 1991b). 
Additionally, the observation that HBx activates the expression of Fas ligand in HCC cell lines (Shin et al., 1999), may provide a way for virus infected cells to escape direct $\mathrm{T}$ cell killing by inducing apoptosis in such T cells. This would not only promote chronicity, but in tumor cells, an escape from immune elimination.

\subsubsection{Up-regulated gene 11 (URG11) and hepatocarcinogenesis}

Another transcript identified by subtractive hybridization in $\mathrm{HBx}$ positive compared to negative HepG2 cells encoded a novel protein provisionally designated as URG11 (Lian et al., 2003). The protein product was about $70 \mathrm{kDa}$ ( 673 amino acids) in size and contained five von Willebrand factor type-C repeats and one C-type lectin domain. Functional characterization showed that over-expression of URG11 significantly stimulated cell growth in culture, anchorage-independent growth in soft agar, accelerated tumor formation, and yielded larger tumors in SCID mice injected subcutaneously with HepG2 cells. Further work showed that HBx trans-activated URG11, and that URG11 trans-activated the $\beta$-catenin promoter. URG11 specific siRNA inhibited the growth of HBx expressing liver cells in serum free medium. The latter was associated with depressed levels of $\beta$-catenin. As

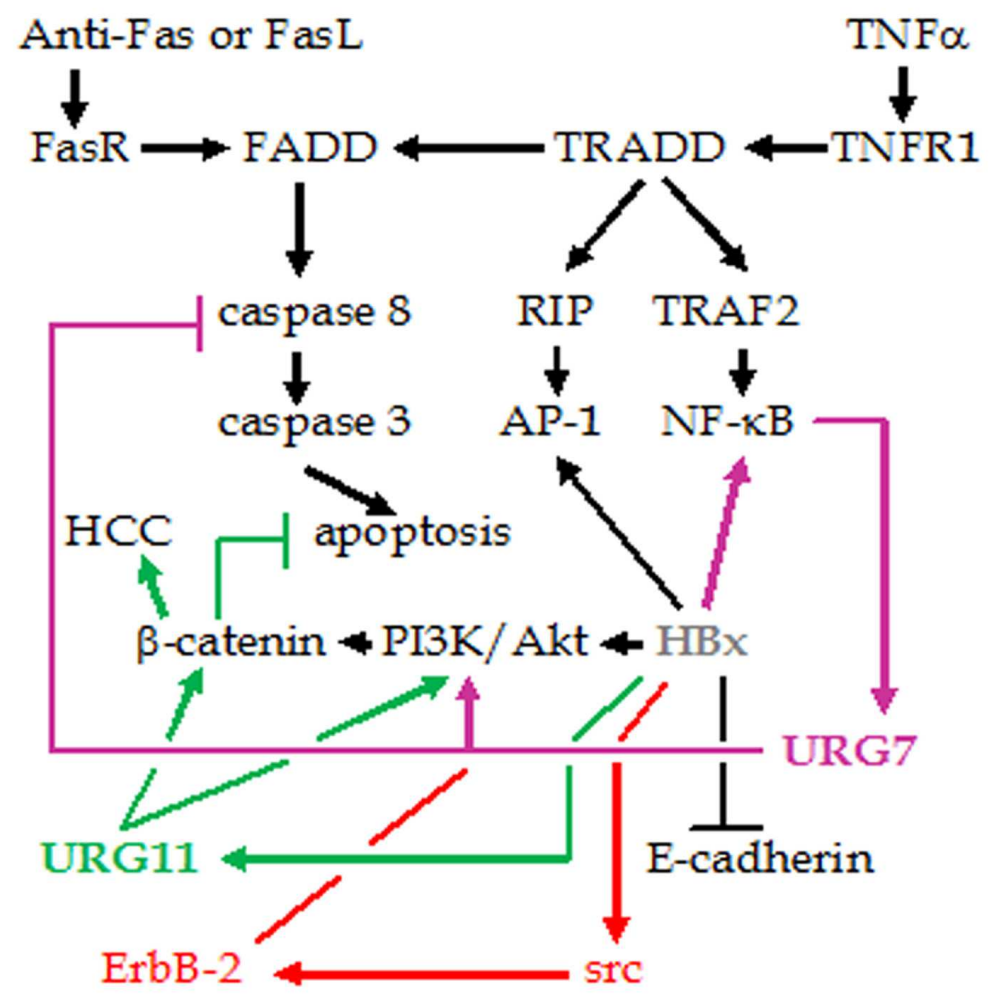

Fig. 2. Model showing selected steps of how HBx inhibits apoptosis and promotes tumorigenesis. HBx alters pathways involving URG7 (in purple), URG11 (in green), and ErbB-2 (in red). See the text for additional details. 
with URG7, there was extensive co-staining between HBx and URG11 in chronically infected liver (Lian et al., 2006) but not in tumor. This suggests that URG11 promotes hepatocellular growth prior to the appearance of HCC. The ability of URG11 specific siRNA to block the growth of liver tumor cells both in vitro and in vivo, not only underscores the importance of elevated URG11 to cell growth, but also suggests that it may be a novel target for the development of specific therapeutics against HCC (Fan et al., 2011). Independent work has recently shown that URG11 was induced under hypoxic conditions in human kidney tubule cells (Du et al., 2010). The latter was associated with increased levels of HIF$1 \alpha$, which is also known to be a target of HBx (Holotnakova et al., 2010). Importantly, HIF-1 $\alpha$ is known to trans-activate VEGF in vivo (Yoo et al., 2003), suggesting that neovascularization may occur in cirrhotic nodules prior to the appearance of HCC. If this occurs during the pathogenesis of chronic hepatitis B, it would most likely be observed in cirrhotic nodules, since this represents a hypoxic environment characterized by high levels of HBx expression (Wang et al., 1991a, 1991b). Interestingly, elevated expression of URG11 in kidney tubule cells was also associated with suppression of E-cadherin, and upregulation of the mesenchymal markers vimentin and alpha-SMA, suggesting that URG11 is associated with EMT. In chronic HBV infection, the development of cirrhosis is accompanied by considerable alterations in the tissue architecture within the liver, implying that URG11 may also play a significant role in tissue remodeling during the pathogenesis of chronic infection.

\subsubsection{Elevated vascular endothelial growth factor receptor 3 (VEGFR-3)}

Vascular endothelial growth factor receptor 3 (VEGFR-3), which is associated with angiogenesis, is a receptor tyrosine kinase that is expressed in lymphatic endothelial cells (Iljin et al., 2001). Binding of VEGFR-3 to the ligands VEGF-C or VEGF-D stimulate lymphangiogenesis (Alitalo \& Carmeliet, 2002), while in carcinogenesis, the production of VEGFs by tumors promote metastases and result in decreased survival (Su et al., 2006). Elevated VEGF has been found in patients with HCC (Dahr et al., 2002, Poon et al., 2003). VEGFR-3 is also expressed in tumor cells from several tumor types (Bando et al., 2004, Su et al., 2006), including HCC (Dahr et al., 2002), implying the existence of an autocrine/paracrine loop that promotes tumor development independent of lymphangiogenesis (Su et al., 2006). In HCC, elevated VEGFR-3 is associated with portal vein invasion of tumors, increased hepatic tumor recurrence, and shorter survival (Dhar et al., 2002), suggesting that VEGFR-3 is important in the pathogenesis of HCC. In this context, differential display of $\mathrm{HBx}$ positive compared to negative cells showed that HBx upregulated the expression of an mRNA which encoded a splice variant of VEGFR-3 (Lian et al., 1997). This was verified at the mRNA and protein levels in HBx positive compared to negative HepG2 cells. In infected liver, expression of VEGFR-3 was prominent in nodules of HCC and correlated with HBx expression. VEGFR-3 stimulated cell cycle in culture, anchorage independent growth in soft agar, and accelerated tumor formation and larger tumor size in SCID mice injected with HepG2 cells over-expressing VEGFR-3. Further work showed that over-expression of VEGFR-3 in the absence of HBx resulted in activation of PI3K/Akt, which then activated $\beta$-catenin gene expression (Figure 2), and with inactivation of the tumor suppressor, PTEN. Interestingly, HBx also mediates these changes, suggesting that they may be actually carried out by up-regulation of VEGFR-3. These findings also suggest that in addition to lymphangiogenesis, VEGFR-3 may promote tumorigenesis in HBx associated HCC. 


\subsubsection{Elevation of $\beta$-catenin and suppression of E-cadherin}

Constitutive activation of $\beta$-catenin is characteristic of many tumor types (Fukuchi et al., 1998; Morin et al., 1997). This results in constitutive Wnt signaling, where $\beta$-catenin translocates to the nucleus and stimulates the expression of genes that promote tumorigenesis (Clevers \& van de Wetering, 1997; Peifer \& Polakis, 2000; Terradillos et al., 1997). Importantly, $\beta$-catenin mutations are found in small HCCs and in preneoplastic liver (Calvisi et al., 2001; Terris et al., 1999,), suggesting they occur early in tumor development. The finding of frequent $\beta$-catenin mutations in a subset of human HCC (de La Costa et al., 1998, Miyoshi et al., 1998), especially in HBV-negative tumors (Hsu et al., 2000), implies that the majority of $\beta$-catenin activation must occur by mechanisms other than mutation. In the chronically infected liver, $\mathrm{HBx}$ has been shown to be associated with the constitutive activation of wild type $\beta$-catenin. The finding that the activation of wild type $\beta$-catenin was associated with URG11 (Lian et al., 2006) and URG7 (Pan et al., 2007), underscores the importance of this activation in hepatocarcinogenesis. Moreover, $\beta$-catenin appears to be stabilized by a number of mechanisms, including trans-activation of the $\beta$-catenin promoter (Lian et al., 2006; Pan et al., 2007), inhibition of proteasomal degradation (Cui et al., 2006; Zhang et al., 2000), and suppression of E-cadherin expression (Arzumanyan et al., 2011; Lee et al., 2005; Liu et al., 2006) (Figure 2). The latter is of particular importance because suppression of the cell adhesion protein, E-cadherin, is a hallmark of EMT, which is important to the pathogenesis of CLD and HCC. The importance of suppressed E-cadherin expression is further underscored by the findings that this occurs by DNA methylation of the E-cadherin promoter (Lee et al., 2005; Liu et al., 2006), by the inhibition miR-373 expression by $\mathrm{HBx}$, and by $\mathrm{HBx}$ mediated stimulation of histone deacetylase (HDAC) at the E-cadherin promoter (Arzumanyan et al., 2011). Independent of the mechanism involved, suppression of E-cadherin has important ramifications upon $\beta$-catenin. Normally, $\beta$-catenin participates in cell adhesion by serving as a link between E-cadherin and the cytoskeleton. When E-cadherin expression is suppressed, $\beta$-catenin is released from this role and translocates to the nucleus where it activates genes that promote cell growth. Thus, in the presence of $\mathrm{HBx}$, there is an inverse correlation with E-cadherin expression, and a direct correlation with the accumulation of cytoplasmic and nuclear $\beta$-catenin at the expense of membranous $\beta$-catenin, both in cultured cells and in clinical specimens (Arzumanyan et al., 2011; Lian et al., 2006; Liu et al., 2006). This suggests a tight coupling between EMT and the promotion of hepatocellular growth prior to the development of HCC (Du et al., 2010).

\subsubsection{Elevated expression of ErbB-2}

Another natural effector of HBx is ErbB-2 (Liu et al., 2009). ErbB-2 (HER2 or neu) is a member of the epidermal growth factor receptor tyrosine kinases that is involved in the transmission of differentiation and proliferation signals (Olayioye et al., 2000, Yarden \& Sliwkowski, 2001). High levels of ErbB-2 have been shown in various types of cancers (Sauter et al., 1993; Slamon et al., 1987; Tanner et al., 1996), and in some tumors, overexpression is associated with poor prognosis. In breast cancer, up-regulated ErbB-2 appears to be an early event, since it appears in tumor and nontumor tissue (Menard et al., 2002). In HCC, elevated ErbB-2 has been reported in hyperplastic nodules (Niu \& Wang, 2005) and in $30-40 \%$ of HCCs (Chen et al., 2002; Neo et al., 2004). However, ErbB-2 was not found in HCC 
tissues from other studies (Alitalo \& Carmeliet, 2002; Hsu et al., 2002; Vlasoff et al., 2002). The finding that HBx up-regulates and stabilizes $\beta$-catenin (Lian et al., 2006), which in some tumors is activated by elevated levels of ErbB-2, suggested that constitutive expression of $\beta$ catenin may be associated with elevated ErbB2. Accordingly, when HBx positive and negative cells were subjected to proteomics analysis, ErbB-2 was up-regulated in $\mathrm{HBx}$ expressing but not control cells. ErbB-2 was also strongly up-regulated in HBV infected liver, where it correlated with HBx expression, and weakly in some HCC nodules (Liu et al., 2009). Among tumor bearing patients, strong ErbB-2 staining in the liver was associated with dysplasia, and a shorter survival after tumor diagnosis. This implies that elevated ErbB-2 is an early marker of HCC. Treatment of HBx expressing cells with ErbB-2 specific siRNA not only reduced ErbB2 expression, but also reduced the expression of $\beta$-catenin, suggesting that ErbB-2 contributed to the stabilization of $\beta$-catenin. ErbB-2 specific siRNA also partially blocked the ability of HBx to promote DNA synthesis and growth of cells in vitro (Liu et al., 2009). These results suggested that ErbB-2/ $\beta$-catenin up-regulation contributed to $\mathrm{HBx}$ mediated hepatocellular growth. The additional finding that $\mathrm{HBx}$ stimulates expression of the epidermal growth factor receptor (EGFR or ErbB1) (Menzo et al.,1993), and that EGFR signaling stabilizes $\beta$-catenin (Takahashi et al., 1997), suggested that EGF signaling may be strongly activated in patients at high risk for HCC or with already established tumors. This suggests that elevated ErbB-2 may be rate limiting in tumor formation, and if so, may be a therapeutic target (Altimari et al., 2003). Further, the accumulation of wild type $\beta$-catenin in the presence of elevated ErbB-2 correlated with the activation of PI3K/Akt signaling, which is known to be activated by HBx and ErbB-2 (Lian et al., 2006; Shih et al., 2000; Yarden \& Sliwkowski, 2001) (Figure 2). PI3K/Akt activity may also be stimulated by src, the latter of which is activated by $\mathrm{HBx}$, early in tumor development (Lara-Pezzi et al., 2001b; Shih et al., 2003). Further, the peptidyl prolyl isomerase, Pin1, is up-regulated in HCC, and is known to stabilize both HBx (Pang et al., 2007) and ErbB-2 (Lam et al., 2008), suggesting a variety of possible mechanisms underlying the close $\mathrm{HBx} /$ ErbB-2 relationship.

\subsubsection{Other natural target genes of HBx}

In addition to transcriptional regulation of gene expression, $\mathrm{HBx}$ up-regulates expression of the ribosomal protein, S15a (Lian et al., 2004) and down-regulates expression of the translation initiation factor, Sui1 (Lian et al., 1999). S15a is a highly conserved protein (Chan et al., 1994; Reed, 1980; Schaap et al., 1995) that promotes mRNA/ribosome interactions early in translation (Lavoie et al., 1994). S15a also stimulates growth in yeast (Pringle et al., 1981; Reed, 1980,), in plants (Bonhan-Smith \& Moloney, 1994; Bonham-Smith et al., 1992) and in human lung carcinoma cells (Akiyama et al., 2000). The observation that S15a stimulates hepatocellular growth and survival in vitro, and tumor formation in vivo, suggests that it also plays a role in hepatocarcinogeneis, and that HBx contributes to transformation, in part, at the level of protein translation by up-regulated expression of S15a (Lian et al., 2004). As stated above,, HBx was also shown to depress the expression of the translation initiation factor, sui1. Sui1, whose function is to work with eIF-2 to enable the initiator tRNAMET to establish ribosomal recognition of an AUG codon (Yoon and Donahue, 1992), suggests that the expression of hu-suil contributes to the regulation of protein translation. In 
vivo work showed that suil was expressed in nontumor liver but not in tumor cells from patients with HCC. Sui1 inhibited cell growth in culture, in soft agar, and partially inhibited tumor formation in nude mice, suggesting that suppression of suil may result in the abrogation of negative growth regulation that contributes to the development of HCC (Lian et al., 1999). Given that S15a and sui1 are both involved in regulating translation, it is likely that $\mathrm{HBx}$ also contributes to HCC by altering gene expression at multiple steps within translation, although the mRNAs that are differentially translated remain to be identified.

$\mathrm{HBx}$ also stimulates the expression of the novel protein, URG4 (Tufan et al., 2002). URG4, encodes a protein of about $104 \mathrm{kDa}$ that was strongly expressed in HBV-infected liver and in HCC cells, where it co-stained with $\mathrm{HBx}$, and was weakly expressed in uninfected liver, suggesting URG4 was an effector of HBx in vivo. Over-expression of URG4 without HBx in human hepatoblastoma cells promoted hepatocellular growth and survival in tissue culture and in soft agar, and accelerated tumor development in nude mice (Tufan et al., 2002). URG4 over-expression was associated with elevated cyclin D1 expression, and treatment of such cells with URG4 specific siRNA reduced both cyclin D1 expression and inhibited cell cycle progression (Tufan et al., 2010). These observations suggest that URG4 may be an oncogene that contributes to HBV associated HCC. Independent work showed that overexpression of URG4 in osteosarcoma tissues directly correlated with tumor recurrence and metastasis, as well as with the proliferative activity of osteosarcoma cells. Patients with high expression of URG4 had shorter survival time, suggesting that URG4 might be rate limiting in carcinogenesis and a valuable prognostic marker in osteosarcoma patients (Huang et al., 2009). Thus, URG4 may contribute to carcinogenesis outside of the liver.

$\mathrm{HBx}$ also appears to up-regulate the expression of insulin - like growth factor 2 (IGF-2) and the IGF-1 receptor in HCC (Kim et al., 1996; Su et al., 1994). The finding that insulin-like growth factor-2 expression, which is normally observed only in fetal liver (Soares et al., 1985), is elevated in HCCs (D'Arville et al., 1991, Cariani et al., 1991), and in premalignant proliferative nodules in the liver (Cariani et al., 1988; D'Arville et al., 1991), suggest that its reactivation may be an early step in the development of this tumor type. The elevation of IGF-2 expression in HCCs from HBV infected but not uninfected patients, combined with the finding of a strong correlation between IGF-2 and HBx in the liver by immunohistochemical staining (Su et al., 1994), suggest that IGF-2 may be a natural target of $\mathrm{HBx}$ during chronic infection. In human hepatoma cell lines, IGF-2 was expressed strongly in growing cells, but was undetectable in confluent cultures (Su et al., 1994), suggesting that it was associated with cell proliferation. At the molecular level, the tumor suppressor, PTEN normally suppresses IGF-2 expression (Kang-Park et al., 2003), but in the presence of HBx, PTEN expression is blocked, resulting in activation of IGF-2 (Chung et al., 2003). Normally, PTEN is up-regulated by another tumor suppressor, p53, but since HBx binds to and inactivates p53 (Feitelson et al., 1993b; Wang et al., 1994), PTEN expression also drops (Chung et al., 2003). In addition, HBx activation of Sp1 via protein kinase C (PKC) and $\mathrm{p} 44 / \mathrm{p} 42 \mathrm{MAPK}$ signaling pathways are also operative in promoting IGF-2 gene expression (Kang-Park et al., 2001). These multiple pathways underscore the importance of IGF-2 upregulation in hepatocarcinogenesis. Finally, the finding that $\mathrm{HBx}$ stimulates the expression of the IGF-1 receptor in human HCC cell lines (Kim et al., 1996), which binds both IGF-1 and IGF-2, suggests that HBx may set up an autocrine loop that enhances cell growth. Thus, the 
up-regulated expression of IGF-2, which appears to be a target of HBx in vivo, may promote hepatocarcinogenesis.

The finding that $\mathrm{HBx}$ interacts with and inhibits the function of the proteasome (Huang et al., 1996) suggests another mechanism whereby HBx could alter gene expression at a posttranslational level. This inhibition appears to be important in supporting HBx transactivation activity (Hu et al., 1999). Given that HBx trans-activates virus gene expression and replication, when mutants of the $X$ protein that bound to and inhibit the proteasome were introduced into WHV, and the resulting virus used for experimental infection, no or transient viremia was observed. In contrast to wild type WHV, which resulted in a high carrier rate among experimentally infected woodchucks, none of the animals infected with the X mutant developed the carrier state (Zhang et al., 2001). Further work in vitro showed that in the presence of proteasome inhibitors, replication of the wild-type virus was not affected, while the replication of the X-negative HBV or WHV was enhanced and restored to the wild-type levels. Similar results were obtained in mouse models replicating wild type and X mutant HBV (Zhang et al., 2010). Thus, HBx appears to affect hepadnavirus replication through a proteasome-dependent pathway (Zhang et al., 2004). Moreover, in the livers of transgenic mice where the levels of HBx expression increased with age, there was a parallel age related decreases in the peptidase activities of the proteasome in the liver ( $\mathrm{Hu}$ et al., 2006). Microarray analysis showed that many of the genes affected involved transcription and cell growth. For example, insulin-like growth factor-binding protein 1 was down-regulated in the HBx mouse liver (Hu et al., 2006), while in vitro, HBx stabilized c-myc (Kalra \& Kumar, 2006) and the protooncoprotein, pituitary tumor-transforming gene 1 (PTTG1) (Molina-Jimenez et al., 2010), by blocking ubiquitination and proteasomal degradation. HBx also differentially regulated the level of $\beta$-catenin through two ubiquitindependent proteasome pathways depending upon the status of p53 (Jung et al., 2007). Given that HBx expression is dominant in liver compared to HCC tissue (Wang et al., 1991a, 1991b), it was not surprising to find an elevated proteasomal activity in HCC compared to surrounding nontumor liver, both in $\mathrm{HBx}$ transgenic mice that developed tumors, and in clinical samples from patients with HCC (Cui et al., 2006). These observations suggest that changes in proteasome function accompany the pathogenesis of CLD and HCC, and that these changes appear to be related to the levels of $\mathrm{HBx}$.

\section{Conclusions}

Tumorigenesis is a multi-step process, and as outlined above, HBx impacts upon this process by targeting selected pathways and genes in natural infection. For most of the target genes presented here, up-regulated or down-regulated expression was established by comparison of gene expression profiles in $\mathrm{HBx}$ positive compared to negative cells, suggesting that they were due to the properties of $\mathrm{HBx}$. Clinical validation was carried out on liver and tumor tissues obtained from HBV infected patients. For up-regulated genes, there was strong co-staining between $\mathrm{HBx}$ and the putative target, while for down-regulated genes, there was an inverse relationship by immunohistochemistry, and in many cases, northern blotting or RT/PCR analyses as well. Moreover, many of the natural targets of HBx discussed herein were characterized to gain at least a preliminary outline as to their contribution to the pathogenesis of HCC. The overall results show that HBx contributes to 
multiple steps in hepatocarcinogenesis, and that the pleiotrophic nature of $\mathrm{HBx}$, known for many years, is now being better understood by the functions of the proteins encoded by these target genes. These data provide crucial information as to the steps in the pathogenesis of HCC that are likely to be rate limiting, which is very important for the application of therapeutic approaches to known targets and for the development of therapeutics to novel targets. The hope embodied in these studies is that they will lead to the development of diagnostic/prognostic biomarkers and/or therapies that will specifically target gene products whose functions appear to be rate limiting in tumorigenesis. The fact that most of the up-regulated genes are over-expressed in liver, and much less often in tumor, means that specific therapies could be devised to ultimately reduce the risk for development of HCC, and if this is achieved, this would open up the probability that chemoprevention could become a realistic approach to treating patients at high risk for the appearance of cancer. This approach will not only be useful, for approaching cancer prevention in the liver, but if one or more of the URGs described above are also elevated in precancerous lesions from other tissue types, the approach would become more widespread in preventing the development of other tumors. In doing so, this has the possibility of establishing a different paradigm for therapeutic approaches against cancer.

\section{Acknowledgements}

This work was supported by grants CA111427, CA104025, and AI076535 awarded to Dr. Mark Feitelson

\section{References}

Akhurst, R.J. (2002). TGF-beta antagonists: why suppress a tumor suppressor?. J Clin Invest 109:1533-1536.

Akiyama, N., Matsuo, Y., Sai, H., Noda, M. \& Kizaka-Kondoh S. (2000). Identification of a series of transforming growth factor beta-responsive genes by retrovirus-mediated gene trap screening. Mol Cell Biol 9:3266-3273.

Alitalo, K. \& Carmeliet. P. (2002). Molecular mechanisms of lymphangiogenesis in health and disease. Cancer Cell 1:219-227.

Altimari, A., Fiorentino, M., Gabusi, E., Gruppioni, E., Corti, B., D’Errico, A. \& Grigioni, W.F. (2003). Investigation of ErbB1 and ErbB2 expression for therapeutic targeting in primary liver tumours. Dig Liver Dis 25:332-338.

Arzumanyan, A., Friedman, T., Kotei, E., Ng, I.O.L., Lian, Z. \& Feitelson, M.A. (2011). Epigenetic repression of E-cadherin expression by hepatitis $\mathrm{B} x$ antigen $(\mathrm{HBx})$ in liver cancer. Oncogene in press.

Assrir, N., Soussan, P., Kremsdorf, D. \& Rossignol, J.M. Role of the hepatitis B virus proteins in pro- and anti-apoptotic processes. Frontiers in Bioscience 15:12-24, 2010.

Balsano, C., Billet, O., Bennoun, M., Cavard, C., Zider, A., Grimber, G., Natoli, G., Briand, P. \& Levrero, M. (1994). Hepatitis B virus $X$ gene product acts as a transactivator in vivo. J Hepatol 21:103-109.

Bando, H., Brokelmann, M., Toi, M., Alitalo, K., Sleeman, J.P., Sipos, B, Gröne, H.J. \& Weich, H.A. (2004). Immunodetection and quantification of vascular endothelial growth factor receptor-3 in human malignant tumor tissues. Int J Cancer 11:184-191. 
Beg, A. \& Baltimore, D. (1996). An essential role for NF-кB in preventing TNF- $\alpha$-induced cell death. Science 274:782-784.

Beg, A., Sha, W., Bronson, R., Ghosh, S. \& Baltimore, D. (1995). Embryonic lethality and liver regeneration in mice lacking the RelA component of NF-кB. Nature 376:167-170.

Belloni, L., Pollicino, T., De Nicola, F., Guerrieri F., Raffa, G., Fanciulli, M., Raimondo, G. \& Levrero M. (2009). Nuclear HBx binds the HBV minichromosome and modifies the epigenetic regulation of cccDNA function. Proc Natl Acad Sci USA 106:19975199799.

Benhenda, S., Cougot, D., Buendia, M.A. \& Neuveut, C. (2009). Hepatitis B virus X protein molecular functions and its role in virus life cycle and pathogenesis. Adv Cancer Res 103:75-109.

Bonham-Smith, P.C. \& Moloney, M.M. (1994). Nucleotide and protein sequences of a cytoplasmic ribosomal protein S15a gene from Arabidopsis thaliana. Plant Physiol 106:401-402.

Bonham-Smith, P.C., Oancia, T.L. \& Moloney, M.M. (1992). Cytoplasmic ribosomal protein S15a from Brassica napus: molecular cloning and developmental expression in mitotically active tissues. Plant Mol Biol 18:909-919.

Bui-Nguyen, T.M., Pakala, S.B., Sirigiri, R.D., Xia, W., Hung, M.C., Sarin, S.K., Kumar, V., Slagle, B.L. \& Kumar, R. (2010). NF-kappaB signaling mediates the induction of MTA1 by hepatitis B virus transactivator protein HBx. Oncogene 29:1179-1189.

Calvisi, D.F., Factor, V.M., Loi, R. \& Thorgeirson, S.S. (2001). Activation of $\beta$-catenin during hepatocarcinogenesis in transgenic mouse models: Relationship to phenotype and tumor grade. Cancer Res 61:2085-2091.

Cariani, E., Lasserre, C., Kemeny, F., Franco, D. \& Brechot, C. (1991). Expression of insulinlike growth factor II, $\alpha$-fetoprotein and HBV transcripts in human primary liver cancer. Hepatology 13:644-649.

Cariani, E., Lasserre, C., Seurin, D., Hamelin, B., Kemeny, F., Franco, D., Czech, M.P., Ullrich, A. \& Brechot, C. (1988). Differential expression of insulin-like growth factor II mRNA in human primary liver cancers, benign liver tumors, and liver cirrhosis. Cancer Res 48:6844-6849.

Castilla, A., Prieto, J. \& Fausto, N. Transforming growth factors beta 1 and alpha in chronic liver disease. (1991). Effects of interferon alpha therapy. N Engl J Med 324:933-940.

Chan, Y.L., Olvera, J., Paz, V. \& Wool, I.G. (1994). The primary structure of rat ribosomal protein S15a. Biochem Biophys Res Commun 200:1498-1504.

Chen, B.F., Liu, C.J., Jow, G.M., Chen, P.J., Kao, J.H. \& Chen, D.S. (2006). High prevalence and mapping of pre-S deletion in hepatitis B virus carriers with progressive liver diseases. Gastroenterology 130:1153-1168.

Chen, H.S., Kaneko, S., Girones, R., Anderson, R.W., Hornbuckle, W.E., Tennant, B.C., Cote, P.J., Gerin, J.L., Purcell, R.H. \& Miller, R.H. (1993). The woodchuck hepatitis virus X gene is important for establishment of virus infection in woodchucks. J Virol 67:1218-1226.

Chen, S., Guttridge, D.C., You, Z.. Zhang, Z.. Fribley, A.. Mayo, MW., Kitajewski, J. \& Wang, C.Y. (2001). Wnt-1 signaling inhibits apoptosis by activating beta-catenin/T cell factor-mediated transcription. J Cell Biol 152:87-96. 
Chen, X., Cheung, S.T., So, S., Fan, S.T., Barry, C., Higgins, J., Lai, K.M., Ji, J., Dudoit, S., Ng, I.O., van de Rijn, M., Botstein, D., et al. (2002). Gene expression patterns in human liver cancers. Mol Biol Cell 13:1929-1939.

Cheng, B., Zheng, Y., Guo, X., Wang, Y. \& Liu, C. (2010). Hepatitis B viral X protein alters the biological features and expressions of DNA repair enzymes in LO2 cells. Liver Intl 30:319-326.

Choi, S.S., Omenetti, A,. Witek, R.P., Moylan, C.A., Syn, W.K., Jung, Y,. Yang, L., Sudan, D.L., Sicklick, J.K., Michelotti, G.A., Rojkind, M. \& Diehl, A.M. (2009). Hedgehog pathway activation and epithelial-to-mesenchymal transitions during myofibroblastic transformation of rat hepatic cells in culture and cirrhosis. Am J Physiol - GI \& Liver Physiol 297:G1093-G1106.

Chung, T.W., Lee, Y.C. \& Kim, C.H. (2004). Hepatitis B viral HBx induces matrix metalloproteinase-9 gene expression through activation of ERK and PI-3K/AKT pathways: involvement of invasive potential. FASEB J 18:1123-1125.

Chung, T.W., Lee, Y.C., Ko, J.H. \& Kim, C.H. (2003). Hepatitis B virus X protein modulates the expression of PTEN by inhibiting the function of p53, a transcriptional activator in liver cells. Cancer Res 63:3453-3458.

Clevers, H. \& van de Wetering, M. (1997). TCF/LEF factor earn their wings. Trends Genet 13:485-489.

Cougot, D., Wu, Y., Cairo, S., Caramel, J., Renard, C.A., Lévy, L., Buendia, M.A. \& Neuveut, C. (2007). The hepatitis B virus $X$ protein functionally interacts with CREB-binding protein/p300 in the regulation of CREB-mediated transcription. J Biol Chem 282:4277-4287.

Cui, F., Wang, Y., Wang, J., Wei, K., Hu, J., Liu, F., Wang, H., Zhao, X., Zhang, X. \& Yang, X. (2006). The up-regulation of proteasome subunits and lysosomal proteases in hepatocellular carcinomas of the HBx gene knockin transgenic mice. Proteomics 6:498-504, 2006.

D'Arville, C.N., Nouri-Aria, K.T., Johnson, P. \& Williams, R. (1991). Regulation of insulinlike growth factor II gene expression by hepatitis B virus in hepatocellular carcinoma. Hepatology 13:310-315.

de La Coste, A., Romannolo, B., Billuart, P., Renard, C.A., Buendia, M.A., Soubrane, O., Fabre, M., Chelly, J., Beldjord, C., Kahn, A. \& Perret, C. (1998). Somatic mutations of the beta-catenin gene are frequent in mouse and human hepatocellular carcinoma. Proc Natl Acad Sci USA 95:8847-8851.

Dhar, D.K., Naora, H., Yamanoi, A., Ono, T., Kohno, H., Otani, H. \& Nagasue, N. (2002). Requisite role of VEGF receptors in angiogenesis of hepatocellular carcinoma: a comparison with angiopoietin/Tie pathway. Anticancer Res 22:379-386.

Diao, J., Khine, A.A., Sarangi, F., Hsu, E., Iorio, C., Tibbles, L.A., Woodgett, J.R., Penninger, J. \& Richardson, C.D. (2001). X protein of hepatitis B virus inhibits Fas-mediated apoptosis and is associated with up-regulation of the SAPK/JNK pathway. J Biol Chem 276:8328-8340.

Doong, D.L., Lin M.H., Tsai, M.M., Li T.R., Chuang, S.E. \& Cheng, A.L. (1998). Transactivation of the human MDR1 gene by hepatitis B X gene product. J Hepatol 29:872-878. 
Du, R., Huang, C., Bi, Q., Zhai, Y., Xia, L., Liu, J., Sun, S. \& Fan, D. (2010). URG11 mediates hypoxia-induced epithelial-to-mesenchymal transition by modulation of Ecadherin and beta-catenin. Biochem Biophys Res Commun 391:135-141.

Fan, R., Li, X., Du, W., Zou, X., Du, R., Zhao, L., Luo, G., Mo, P., Xia, L., Pan, Y., Shi, Y., Lian, Z., Feitelson, M.A., Nie, Y., Liu, J. \& Fan D. (2011). Adenoviral-mediated RNA interference targeting URG11 inhibits growth of human hepatocellular carcinoma. Intl J Cancer 128:2980-2993.

Feitelson, M.A. \& Duan, L.X. (1997). Hepatitis B virus X antigen in the pathogenesis of chronic infections and the development of hepatocellular carcinoma. Am J Pathol 150:1141-1157.

Feitelson, M.A., Lega, L., Duan, L.X., \& Clayton, M. (1993a). Characteristics of woodchuck hepatitis $X$ antigen in the livers and sera from chronically infected animals. $J$ Hepatol 17(Suppl. 3):S24-S34.

Feitelson, M.A., Reis, H., Liu, J., Lian, Z. \& Pan, J. (2005). Hepatitis B virus X antigen (HBxAg) and cell cycle control in chronic infection and hepatocarcinogenesis. In: Frontiers in Bioscience. Viral Infection and Cell Cycle Control, Zhao R., ed., Frontiers in Bioscience, Albertson, N.Y., USA, pp. 1558-1572.

Feitelson, M.A., Reis, H., Tufan, L.S., Liu, J., Zhu, M., Pan, J. \& Lian, Z. (2008). Hepatitis B x antigen interference with tumor suppressor pathways in hepatocarcinognesis. In: The Pleiotropic Functions of the Viral protein HBx in HBV Infection and the Development of Liver Cancer, Kobarg, J., ed., Research Signpost, Kerala, India, pp. 1-18.

Feitelson MA, Reis HMGPV, Tufan NL, Sun B, Pan J, Lian Z. (2009). Putative roles of hepatitis $\mathrm{B} \times$ antigen in the pathogenesis of chronic liver disease. Cancer Letters 286:69-79.

Feitelson, M.A., Sun, B., Tufan, N L., Liu, J., Pan, J. \& Lian, Z. (2002). Genetic mechanisms of hepatocarcinogenesis. Oncogene 21:2593-2604.

Feitelson, M.A., Zhu, M., Duan, L.X. \& London, W.T. (1993b). Hepatitis B X antigen and p53 are associated in vitro and in liver tissues from patients with primary hepatocellular carcinoma. Oncogene 8:1109-1117.

Flisiak, R., Al-Kadasi, H., Jaroszewicz, J., Prokopowicz, D. \& Flisiak, I. (2004). Effect of lamivudine treatment on plasma levels of transforming growth factor beta1, tissue inhibitor of metalloproteinases- 1 and metalloproteinase- 1 in patients with chronic hepatitis B. World J. Gastroenterol 10:2661-2665.

Fukuchi, T., Sakamoto, M., Tsuda, H., Maruyama, K., Nozawa, S. \& Hirohashi, S. (1998). $\beta$ Catenin mutation in carcinoma of the uterine endometrium. Cancer Res 58:35263528 .

Gottlob, K., Fulco, M., Levrero, M. \& Graessmann, A. (1998). The hepatitis B virus HBx protein inhibits caspase 3 activity. J Biol Chem 273:33347-33353.

Guo, G.H., Tan, D.M., Zhu, P.A. \& Liu, F. (2009). Hepatitis B virus X protein promotes proliferation and upregulates TGF-beta1 and CTGF in human hepatic stellate cell line, LX-2. Hepatobil Panc Dis Intl 8:59-64.

Haviv, I., Vaizel, D. \& Shaul, Y. (1995). The X protein of hepatitis B virus coactivates potent activation domains. Mol Cell Biol 15:1079-1085. 
Haviv, I., Vaizel, D. \& Shaul, Y. (1996). pX, the HBV-encoded coactivator, interacts with components of the transcription machinery and stimulates transcription in a TAFindependent manner. EMBO J 15:3413-3420.

Henkler, F. \& Koshy, R. (1996). Hepatitis B virus transcriptional activators: mechanisms and possible role in oncogenesis. J Viral Hepat 3:109-121.

Holotnakova, T.,Tylkova, L., Takacova, M., Kopacek, J., Petrik, J., Pastorekova, S. \& Pastorek, J. (2010). Role of the HBx oncoprotein in carbonic anhydrase 9 induction. J Med Virol 82:32-40.

Hsu, C., Huang, C.L., Hsu, H.C., Lee, P.H., Wang, S.J. \& Cheng, A.L. (2002). HER-2/neu overexpression is rare in hepatocellular carcinoma and not predictive of anti-HER2/neu regulation of cell growth and chemosensitivity. Cancer 94:415-420.

Hsu, H.C., Jeng, Y.M., Mao, T.L., Chu, J.S., Lai, P.L. \& Peng, S.Y. (2000). $\beta$-Catenin mutations as associated with a subset of low stage hepatocellular carcinoma negative for hepatitis B virus with favorable prognosis. Am J Pathol 157:763-770.

Hu, Z., Zhang, Z., Doo, E., Coux, O., Goldberg, A.L. \& Liang, T.J. (1999). Hepatitis B virus X protein is both a substrate and a potential inhibitor of the proteasome complex. $J$ Virol 73:7231-7240.

Hu, Z., Zhang, Z., Kim, J.W., Huang, Y. \& Liang, T.J. (2006). Altered proteolysis and global gene expression in hepatitis B virus X transgenic mouse liver. J Virol 80:1405-1413.

Huang, J., Kwong, J., Sun, E.C. \& Liang, T.J. (1996). Proteasome complex as a potential cellular target of hepatitis B virus $X$ protein. J Virol 70:5582-5591.

Huang, J., Zhu, B., Lu, L., Lian, Z., Wang, Y., Yang, X., Tufan, N.L.S., Liu, J. \& Luo, Z. (2009). The expression of novel gene URG4 in osteosarcoma: Correlation with patients' prognosis. Pathology 41:149-154.

Iljin, K., Karkkainen, M.J., Lawrence, E.C., Kimak, M.A., Uutela, M., Taipale, J., Pajusola, K., Alhonen, L., Halmekyto, M., Finegold, D.N., Ferrell, R.E. \& Alitalo, K. (2001). VEGFR3 gene structure, regulatory region, and sequence polymorphisms. FASEB J 15:1028-1036.

Jin, Y.M., Yun, C., Park, C., Wang, H.J., \& Cho, H. (2001). Expression of hepatitis B virus X protein is closely correlated with the high periportal inflammatory activity of liver diseases. J Viral Hepat 8:322-330.

Jung, J.K., Kwun, H.J., Lee, J.O., Arora, P. \& Jang, K.L. (2007). Hepatitis B virus X protein differentially affects the ubiquitin-mediated proteasomal degradation of betacatenin depending on the status of cellular p53. J Gen Virol 88:2144-2154.

Kalra, N. \& Kumar, V. (2006). The X protein of hepatitis B virus binds to the F box protein Skp2 and inhibits the ubiquitination and proteasomal degradation of c-Myc. FEBS Lett 580:431-436.

Kang-Park, S., Lee, J.H., Shin, J.H. \& Lee, Y.I. (2001). Activation of the IGF-II gene by HBV-X protein requires PKC and p44/p42 map kinase signalings. Biochem Biophys Res Commun 283:303-307.

Kang-Park, S., Lee, Y.I. \& Lee, Y.I. (2003). PTEN modulates insulin-like growth factor II (IGF-II)-mediated signaling; the protein phosphatase activity of PTEN downregulates IGF-II expression in hepatoma cells. FEBS Lett 545:203-208. 
Keasler, V.V., Hodgson, A.J., Madden, C.R. \& Slagle, B.L. (2009). Hepatitis B virus HBx protein localized to the nucleus restores $\mathrm{HBx}$-deficient virus replication in HepG2 cells and in vivo in hydrodynamically-injected mice. Virology 390:122-129.

Kew, M.C. (2011). Hepatitis B virus x protein in the pathogenesis of hepatitis B virusinduced hepatocellular carcinoma. J Gastroenterol Hepatol 26(Suppl 1):144-152.

Kim, H.Y., Cho, H.K., Hong, S.P. \& Cheong, J. (2011). Hepatitis B virus X protein stimulates the Hedgehog-Gli activation through protein stabilization and nuclear localization of Gli1 in liver cancer cells. Cancer Lett 309:176-184.

Kim, S.O,, Park, J.G. \& Lee, Y.I. (1996). Increased expression of the insulin - like growth factor I (IGF - I) receptor gene in hepatocellular carcinoma cell lines: implications of IGF - I receptor gene activation by hepatitis B virus $X$ gene product. Cancer Res 56:3831 - 3836.

Klein, N.P. \& Schneider, R.J. (1997). Activation of src family kinases by hepatitis B virus HBx protein and coupled signaling to ras. Mol Cell Biol 17:6427-6436.

Kong, G., Zhang, J., Zhang, S., Shan, C., Ye, L. \& Zhang, X. (2011). Up-regulated microRNA29 a by hepatitis $B$ virus $X$ protein enhances hepatoma cell migration by targeting PTEN in cell culture model. PLoS One 6:e19518

Kumar, M., Jung, S.Y., Hodgson, A.J., Madden, C.R., Qin, J. \& Slagle, B.L. (2011). Hepatitis B virus regulatory $\mathrm{HBx}$ protein binds to adaptor protein IPS-1 and inhibits the activation of beta interferon. J Virol 85:987-995.

Lam, P.B., Burga, L.N., Wu, B.P., Hofstatter, E.W., Lu, K.P. \& Wulf, G.M. (2008). Prolyl isomerase Pin1 is highly expressed in Her2-positive breast cancer and regulates erbB2 protein stability. Mol Cancer 7:91-102.

Lara-Pezzi, E., Majano, P.L., Gómez-Gonzalo, M., García-Monzón, C., Moreno-Otero, R., Levrero, M. \& López-Cabrera, M. (1998). The hepatitis B virus X protein upregulates tumor necrosis factor alpha gene expression in hepatocytes. Hepatology 8:1013-1021.

Lara-Pezzi, E., Majano, P.L., Yanez-Mo, M., Gomez-Gonzalo, M., Carretero, M., MorenoOtero, R., et al, (2001a). Effect of the hepatitis B virus HBx protein on integrinmediated adhesion to and migration on extracellular matrix. J Hepatol 34:409-415.

Lara-Pezzi, E., Roche, S., Andrisani, O.M., Sanchez-Madrid, F. \& Lopez-Cabrera, M. (2001b). The hepatitis B virus protein induces adherens junction disruption in a srcdependent manner. Oncogene 20:3323-3331.

Lauer, U., Weissm L., Hofschneiderm P.H. \& Kekule, A.S. (1992). The hepatitis B virus pre$\mathrm{S} / \mathrm{S}(\mathrm{t})$ transactivator is generated by $3^{\prime}$ truncations within a defined region of the $S$ gene. J Virol 66:5284-5289.

Lavoie, C., Tam, R., Clark, M., Lee, H., Sonenberg, N. \& Lasko, P. (1994). Suppression of a temperature-sensitive cdc33 mutation of yeast by a multicopy plasmid expressing a Drosophila ribosomal protein. J Biol Chem 269:14625-14630.

Lee, D.K., Park, S.H., Yi, Y., Choi, S.G., Lee, C., Parks, W.T., Cho H.S., de Caestecker, M.P., Shaul, Y., Roberts, A.B. \& Kim, S.J. (2001). The hepatitis B virus encoded oncoprotein $\mathrm{pX}$ amplifies TGF- $\beta$ family signaling through direct interaction with Smad4: potential mechanism of hepatitis B virus-induced liver fibrosis. Genes Dev 15:455-466. 
Lee, J.O., Kwun, H.J., Jung, J.K., Choi, K.H., Min, D.S. \& Jang, K.L. (2005). Hepatitis B virus X protein represses E-cadherin expression via activation of DNA methyltransferase 1. Oncogene 24:6617-6625.

Lee, Y.I., Kang-Park, S., Do, S.I. \& Lee, Y.I. (2001). The hepatitis B virus-X protein activates a phosphatidylinositol 3-kinase-dependent survival signaling cascade. J Biol Chem 276:16969-16977.

Lian, Z., Liu, J., Li, L., Li, X., Arbuthnot, P., Kew, M. \& Feitelson, M.A. (2004). Human S15a is an effector which is up-regulated by HBV X protein. Mol Carcinogen 40:34-46.

Lian, Z., Liu, J., Li, L., Li, X., Clayton, M., Wu, M. C., Wang, H. Y., Arbuthnot, P., Kew, M. \& Feitelson, M.A. (2006). Enhanced cell survival of Hep3B cells by the hepatitis B $\mathrm{x}$ antigen effector, URG11, is associated with up-regulation of $\beta$-catenin. Hepatology 43:415-424.

Lian Z. Liu J. Li, L. Li, X. Tufan, N.L., Clayton, M., Wu, M.C., Wang, H.Y., Arbuthnot, P.. Kew, M. \& Feitelson, M.A. (2003). Up-regulated expression of a unique gene by hepatitis B $\mathrm{x}$ antigen promotes hepatocellular growth and tumorigenesis. Neoplasia 5:229-244.

Lian, Z., Liu, J., Pan, J., Tufan, N.L.S., Zhu, M., Arbuthnot, P., Kew, M., Clayton, M.M. \& Feitelson M.A. (2001). A cellular gene up-regulated by hepatitis B virus encoded $X$ antigen promotes hepatocellular growth and survival. Hepatology 34:146-157.

Lian, Z., Pan, J., Liu, J., Zhu, M., Arbuthnot, P., Kew, M.C. \& Feitelson, M.A. (1999). The translation initiation factor, SUI1, may be a target of hepatitis B $\mathrm{x}$ antigen in hepatocarcinogenesis. Oncogene 18:1677-1687.

Liu, F., Li, B. \& Nan, Y. (1999). The effect of serum TGF $\beta 1$ of patients with chronic hepatitis B in liver fibrosis. Chin J Hepatol 7:196-198.

Liu, J., Ahiekpor, A., Li, L., Li, X., Arbuthnot, P., Kew, M. \& Feitelson, M.A. (2009). Increased expression of c-erbB-2 in liver is associated with HBxAg expression and shorter survival in patients with hepatocellular carcinoma. Intl J Cancer 125:1894-1901.

Liu, J., Lian, Z., Han, S., Waye, M.M.Y., Wang, H., Wu, M.C., Wu, K., Ding, J., Arbuthnot, P., Kew, M., Fan, D. \& Feitelson, M.A. (2006). Down-regulation of E-cadherin by hepatitis B virus $x$ antigen in hepatocellular carcinoma. Oncogene 25:1008-1017.

Liu, H., Shi, W., Luan, F., Xu, S., Yang, F., Sun, W., Liu, J. \& Ma, C. (2010). Hepatitis B virus $X$ protein up-regulates transcriptional activation of human telomerase reverse transcriptase. Virus Genes 40:174-182.

Martin-Lluesma, S., Schaeffer, C., Robert, E.I., van Breugel, P.C., Leupin, O., Hantz, O. \& Strubin, M. (2008). Hepatitis B virus X protein affects $S$ phase progression leading to chromosome segregation defects by binding to damaged DNA binding protein 1 . Hepatology 48:1467-1476.

Martin-Vilchez, S., Sanz-Cameno, P., Rodriguez-Munoz, Y., Majano, P.L., Molina-Jimenez, F., Lopez-Cabrera, M., Moreno-Otero, R. \& Lara-Pezzi, E. (2008). The hepatitis B virus $X$ protein induces paracrine activation of human hepatic stellate cells. Hepatology 47:1872-1883.

Mathonnet, G., Lachance, S.. Alaoui-Jamali, M. \& Drobetsky, E.A. (2004). Expression of hepatitis $\mathrm{B}$ virus $\mathrm{X}$ oncoprotein inhibits transcription-coupled nucleotide excision repair in human cells. Mutat Res 554:305-318. 
Menard, S., Casalini, P., Campiglio, M., Pupa, S.M. \& Tagliabue, E. (2002). Role of HER2/neu in tumor progression and therapy. Cell Mol Life Sci 61:2965-2978.

Menzo, S., Clementi, M., Alfani, E., Bagnarelli, P., Iacovacci, S., Manzin, A., Dandri, M., Natoli, G., Levrero, M. \& Carloni, G. (1993). Trans-activation of epidermal growth factor receptor gene by the hepatitis B virus X-gene product. Virology 196:878-882.

Miyoshi, Y., Iwao, K., Nagasawa, Y., Aihara, T., Sasaki, Y., Imaoka, S., Murata, M., Shimano, T. \& Nakamura, Y. (1998). Activation of the beta-catenin gene in primary hepatocellular carcinoma by somatic alterations involving exon 3. Cancer Res 58:2524-2527.

Molina-Jimenez, F., Benedicto, I., Murata, M., Martin-Vilchez, S., Seki T., Antonio PintorToro, J., Tortolero, M., Moreno-Otero, R., Okazaki, K., Koike, K., Barbero, J.L., Matsuzaki, K., Majano, P.L. \& Lopez-Cabrera, M. (2010). Expression of pituitary tumor-transforming gene 1 (PTTG1)/securin in hepatitis B virus (HBV)-associated liver diseases: evidence for an HBV X protein-mediated inhibition of PTTG1 ubiquitination and degradation. Hepatology 51:777-787.

Morin, P.J., Sparks, A.B., Korinek, V., Barker, N., Clevers, H., Vogelstein, B. \& Kinzler, K.W. (1997). Activation of $\beta$-catenin-Tcf signaling in colon cancer by mutations in $\beta$ catenin or APC. Science 275:1787-1790.

Murata, M., Matsuzaki, K., Yoshida, K., Sekimoto, G., Tahashi, Y., Mori, S., Uemura, Y., Sakaida, N., Fujisawa, J., Seki, T., Kobayashi, K., Yokote, K., Koike, K. \& Okazaki, K. (2009). Hepatitis B virus $X$ protein shifts human hepatic transforming growth factor (TGF) $\beta$ signaling from tumor suppression to oncogenesis in early chronic hepatitis B. Hepatology 49:1203-1217.

Myullyla, R., Wang, C., Keikkinen, J., Juffer, A., Lampela, O. Risteli, M., Ruotsalainen, H., Salo, A. \& Sipilä, L. (2007). Expanding the lysyl hydroxylase toolbox: New insights into the localization and activities of lysyl hydroxylase 3 (LH3). J Cell Physiol 212:323-329.

Neo, S.Y., Leow, C.K., Vega, V.B., Long, P.M., Islam, A.F.M., Lai, P.B.S., Liu, E.T. \& Ren, E.C. (2004). Identification of discriminators of hepatoma by gene expression profiling using a minimal dataset approach. Hepatology 39:944-953.

Niu, Z.S. \& Wang, M. (2005). Expression of c-erbB-2 and glutathione S-transferase-pi in hepatocellular carcinoma and its adjacent tissue. World J Gastroenterol 11:4404-4408.

Norton, P.A., Reis, M., Prince, S., Larkin, J., Pan, J., Liu, J., Gong, Q., Zhu, M. \& Feitelson, M.A. (2004). Activation of fibronection gene expression by hepatitis $B$ virus $X$ antigen. J Viral Hepat 11:332-341.

Oishi, N., Shilagardi, K., Nakamoto, Y., Honda, M., Kaneko, S. \& Murakami, S. (2007). Hepatitis $B$ virus $X$ protein overcomes oncogenic RAS-induced senescence in human immortalized cells. Cancer Sci. 98:1540-1548.

Olayioye, M.A., Neve, R.M., Lane, H.A. \& Hynes, N.E. (2000). The ErbB signaling network: receptor heterodimerization in development and cancer. EMBO J 19:3159-3167.

Omenetti, A., Bass, L.M., Anders, R.A., Clemente, M.G., Francis, H.. Guy, C.D., McCall, S., Choi, S.S., Alpini, G.. Schwarz, K.B., Diehl, A.M. \& Whitington, P.F. (2011). Hedgehog activity, epithelial-mesenchymal transitions, and biliary dysmorphogenesis in biliary atresia. Hepatology 53:1246-1258. 
Omenetti, A. \& Diehl, A.M. (2008). The adventures of sonic hedgehog in development and repair. II. Sonic hedgehog and liver development, inflammation, and cancer. Am J Physiol - GI \& Liver Physiol 294:G595-G598.

Pan, J., Clayton, M.M. \& Feitelson, M.A. (2004). Hepatitis B x antigen promotes transforming growth factor $\beta 1$ (TGF $\beta 1$ ) activity by up-regulation of TGF $\beta 1$ and down-regulation of alpha 2- macroglobulin. J Gen Virol 85:275-282.

Pan, J., Duan, L.X., Sun, B.S. \& Feitelson, M.A. (2001). Hepatitis B virus X protein decreases the anti-Fas induced apoptosis in human liver cells by inducing NF-кB. J Gen Virol 82(Part 1):171-182.

Pan, J., Lian, Z., Wallett, S. \& Feitelson, M.A. (2007). The hepatitis B x antigen effector, URG7, blocks tumour necrosis factor alpha-mediated apoptosis by activation of phosphoinositol 3-kinase and beta-catenin. J Gen Virol 8:3275-3285.

Pang, R., Lee, T.K., Poon, R.T., Fan, S.T., Wong, K.B., Kwong, Y.L. \& Tse, E. (2007). Pin1 interacts with a specific serine-proline motif of hepatitis B virus X-protein to enhance hepatocarcinogenesis. Gastroenterology 132:1088-1103.

Park, S.G., Chung, C., Kang, H., Kim, J.Y. \& Jung, G. (2006). Up-regulation of cyclin D1 by HBx is mediated by NF-kappaB2/BCL3 complex through kappaB site of cyclin D1 promoter. J Biol Chem 281:31770-31777.

Park, S.H., Jung, J.K., Lim, J.S., Tiwari, I. \& Jang, K.L. (2011). Hepatitis B virus X protein overcomes all-trans-retinoic acid-induced cellular senescence by down-regulating levels of p16 and p21 via DNA methylation. J Gen Virol 92:1309-1317.

Peifer, M. \& Polakis, P. (2000). Wnt signaling in oncogenesis and embryogenesis - a look outside the nucleus. Science 287:1606-1609.

Pereira, T.A., Witek, R.P., Syn, W.K., Choi, S.S., Bradrick, S.. Karaca, G.F., Agboola, K.M., Jung, Y., Omenetti, A.. Moylan, C.A., Yang, L., Fernandez-Zapico, M.E., Jhaveri, R.. Shah, V.H., Pereira, F.E. \& Diehl, A.M. (2010). Viral factors induce Hedgehog pathway activation in humans with viral hepatitis, cirrhosis, and hepatocellular carcinoma. Lab Invest 90:1690-1703.

Poon, R.T.P., Lau, C.P.K., Cheung, S.T., Yu, W.C. \& Fan, S.T. (2003). Quantitative correlation of serum levels and tumor expression of vascular endothelial growth factor in patients with hepatocellular carcinoma. Cancer Res 63:3121-3126.

Pringle, J.R. \& Hartwell, L.H. (1981). The Saccharomyces cerevisiae cell cycle. In: The Molecular Biology of the Yeast Sacharomyces cerevisiae: Life Cycle and Inheritance. Strathern, J.N., Jones, E.W. \& Broach, J.R., eds. Cold Spring Harbor Laboratory Press, Cold Spring Harbor, N.Y., USA, p. 97-142.

Qadri, I., Fatima, K. \& AbdeL-Hafiz, H. (2011). Hepatitis B virus X protein impedes the DNA repair via its association with transcription factor, TFIIH. BMC Microbiol 11:48.

Reed, S.I. (1980). The selection of S. cerevisiae mutants defective in the start event of cell division. Genetics 95, 561-577.

Rossner, M.T. (1992). Hepatitis B virus X-gene product: a promiscuous transcriptional activator. J Med Virol 36:101-117.

Salo, A.M., Wang, C., Sipila, L., Sormunen, R., Vapola, M., Kervinen, P., Ruotsalainen, H., Heikkinen, J. \& Myllylä, R. (2006). Lysyl hydroxylase 3 (LH3) modifies proteins in the extracellular space, a novel mechanism for matrix remodeling. J Cell Physiol 207:644-653. 
Sanderson, N., Factor, VB., Nagy, P., Kopp, J., Kondaiah, P., Wakefield, L., Roberts, A.B., Sporn, M.B. \& Thorgeirsson, S.N. (1995). Hepatic expression of mature transforming growth factor $\beta 1$ in transgenic mice results in multiple tissue lesions. Proc Natl Acad Sci USA 92:2572-2576.

Sauter, G., Moch, H., Moore, D., Carroll, P., Kerschmann, R. \& Chew, K. (1993). Heterogeneity of erbB-2 gene amplification in bladder cancer. Cancer Res 53:21992203.

Schaap, P.J., de Groot, P.W., Muller, Y., van Griensven, L.J. \& Visser, J. (1995). Molecular cloning and sequence of the cytoplasmic ribosomal protein S15a gene from Agaricus bisporus. Exp Mycol 19:160-162.

Shih, W.L., Kuo, M.L., Chuang, S.E., Cheng, A.L. \& Doong, S.L. (2000). Hepatitis B virus X protein inhibits transforming growth factor-beta -induced apoptosis through the activation of phosphatidylinositol 3-kinase pathway. J Biol Chem 275:25858-25864.

Shih, W.L., Kuo, M.L., Chuang, S.E., Cheng, A.L. \& Doong, S.L. (2003). Hepatitis B virus X protein activates a survival signaling by linking SRC to phosphatidylinositol 3kinase. J Biol Chem 278:31807-31813.

Shin, E.C., Shin, J.S., Park, J.H., Kim, H. \& Kim, S.J. (1999). Expression of Fas ligand in human hepatoma cell lines: role of hepatitis B virus $X(\mathrm{HBx})$ in induction of Fas ligand. Int J Cancer 82:587-591.

Slamon, D.J., Clark, G.M., Wong, S.G., Levin, W.J., Ullrich, A. \& McGuire, W.L. (1987). Human breast cancer: correlation of relapse and survival with amplification of the HER-2/neu oncogene. Science 235:177-182.

Soares, M.B., Ishii, D.N. \& Efstratiadis, A. (1985). Developmental and tissue-specific expression of a family of transcripts related to rat insulin-like growth factor II mRNA. Nucleic Acids Res 14:1119-1134.

Spandau, D.F. \& Lee, C.H. (1988). Trans-activation of viral enhancers by the hepatitis B virus X protein. J Virol 62:427-434.

Su, F. \& Schneider, R.J. (1996). Hepatitis B virus HBx protein activates transcription factor NF-kappaB by acting on multiple cytoplasmic inhibitors of rel-related proteins. $J$ Virol 70:4558-4566.

Su, J.L., Yang, P.C., Shih, J.Y., Yang, C.Y., Wei, L.H., Hsieh, C.Y., Chou, C.H., Jeng, Y.M., Wang, M.Y., Chang, K.J., Hung, M.C. \& Kuo, M.L. (2006). The VEGF-C/Flt-4 axis promotes invasion and metastasis of cancer cells. Cancer Cell 9:209-223.

Su, Q., Liu, J.F., Zhang, S.X., Li, D.F. \& Yang, J.J. (1994). Expression of insulin-like growth factor II in hepatitis B, cirrhosis and hepatocellular carcinoma: Its relationship with hepatitis B virus antigen expression. Hepatology 19:788-799.

Sung, W.K., Lu, Y., Lee, C.W., Zhang, D., Ronaghi, M \&, Lee, C.G. (2009). Deregulated direct targets of the hepatitis $B$ virus $(\mathrm{HBV})$ protein, $\mathrm{HBx}$, identified through chromatin immunoprecipitation and expression microarray profiling. J Biol Chem 284:2194121954.

Takahashi, K., Suzuki, K. \& Tsukatani, Y. (1997). Induction of tyrosine phosphorylation and association of $\beta$-catenin with EGF receptor upon tryptic digestion of quiescent cells at confluence. Oncogene 15:71-78. 
Tanner, B., Kreutz, E., Weikel, W., Meinert, R., Oesch, F., Knapstein, P.G. \& Becker, R. (1996). Prognostic significance of c-erbB-2 mRNA in ovarian cancinoma. Gynecol Oncol 62:268-77.

Tennant, B.C. \& Gerin, J.L. (2001). The woodchuck model of hepatitis B virus infection. Ilar J 42:89-102.

Terradillos, O., Billet, O., Renard, C.A., Levy, R., Molina, T., Briand, P. \& Buendia, M.A. (1997). The hepatitis B virus X gene potentiates c-myc-induced liver oncogenesis in transgenic mice. Oncogene 14:395-404.

Terris, B., Pineau, P., Bregeaud, L., Valla, D., Belghiti, J., Tiollais, P., Degott, C. \& Dejean A. (1999). Close correlation between beta-catenin gene alterations and nuclear accumulation of the protein in human hepatocellular carcinoma. Oncogene 18:65836588.

Tsuge, M., Hiragam, N., Akiyamam, R., Tanakam, S., Matsushitam, M., Mitsuim, F., Abem, H., Kitamura, S., Hatakeyama, T., Kimura, T., Miki, D., Mori, N., Imamura, M., Takahashi, S., Hayes, C.N. \& Chayama K. (2010). HBx protein is indispensable for development of viraemia in human hepatocyte chimeric mice. J Gen Virol 91:18541864 .

Tufan, N.L.S, Dodurga, Y., Gok, D., Cetinkaya, A. \& Feitelson, M.A. (2010). RNA interference-mediated URG4 gene silencing diminishes cyclin D1 mRNA expression in HepG2 cells. Genet Mol Res 9:1557-1567.

Tufan, N.L.S., Lian, Z., Liu, J., Pan, J., Arbuthnot, P., Kew, M., Clayton, M.M. \& Feitelson, M.A. (2002). Hepatitis B $x$ antigen stimulates expression of a novel cellular gene, URG4, that promotes hepatocellular growth and survival. Neoplasia 4:355-368.

Twu, J.S. \& Schloemer, R.H. (1987). Transcriptional trans-activating function of hepatitis B virus. J Virol 61:3448-3453.

Ueda, H., Ullrich, S.J., Ngo, L., Gangemi, D., Kappel, C.A., Feitelson, M.A. \& Jay, G. (1995). Functional inactivation but not structural mutation of p53 causes liver cancer. Nat Genet 9: 41-47.

Varner, J.A., Emerson, D.A. \& Juliano, R.L. (1995). Integrin alpha 5 beta 1 expression negatively regulates cell growth: reversal by attachment to fibronectin. Mol Biol Cell 6:725-740.

Vlasoff, D.M., Baschinsky, D.D.Y., De Young, B.R., Morrison, C.D., Nuovo, G.J. \& Frankel, W.L. (2002). C-erb B2 (HER2/neu) is neither over-expressed nor amplified in hepatic neoplasms. Applied Immunohistochem Mol Morphol 10:237-241.

Wang, W., London, W.T., Lega, L. \& Feitelson, M.A. (1991a). Hepatitis B x antigen in liver from carrier patients with chronic hepatitis and cirrhosis. Hepatology 14:29-37.

Wang, W., London, W.T., \& Feitelson, M.A. (1991b). Hepatitis B x antigen in hepatitis B virus carrier patients with liver cancer. Cancer Res 51:4971-4977.

Wang, X.W., Forrester, K., Yeh, H., Feitelson, M.A., Gu, J.-r. \& Harris, C.C. (1994). Hepatitis $B$ virus $X$ protein inhibits p53 sequence-specific DNA binding, transcriptional activity and association with ERCC3. Proc Natl Acad Sci (USA) 91:2230-2234.

Wei, C., Ni, C., Song, T., Liu, Y., Yang, X., Zheng, Z., Jia, Y., Yuan, Y., Guan, K., Xu, Y., Cheng, X., Zhang, Y., Yang, X., Wang, Y., Wen, C., Wu, Q., Shi, W. \& Zhong, H. (2010). The hepatitis B virus $X$ protein disrupts innate immunity by downregulating mitochondrial antiviral signaling protein. J Immunol 185:1158-1168. 
Weng, H.L., Liu, Y., Chen, J.L., Huang, T., Xu, L.J., Godoy, P.. Hu, J.H., Zhou, C., Stickel, F., Marx, A., Bohle, R.M., Zimmer, V., Lammert, F., Mueller, S., Gigou, M., Samuel, D., Mertens, P.R., Singer, M.V., Seitz, H.K. \& Dooley, S. (2009). The etiology of liver damage imparts cytokines transforming growth factor beta1 or interleukin-13 as driving forces in fibrogenesis. Hepatology 50:230-243.

Wu, G.C., Forgues, M., Siddique, S., Farnsworth, J., Valerie, K. \& Wang, X.W. (2002). SAGE transcript profiles of normal primary human hepatocytes expressing oncogenic hepatitis B virus X protein. FASEB J 16:1665-1667.

Wu, G.C., Salvay, D.M., Forgues, M., Valerie, K., Farnsworth, J., Markin, R.S. \& Wang, X.W. (2001). Distinctive gene expression profiles associated with hepatitis B x protein. Oncogene 20:3674-3682.

Wu, G., Yu, F., Xiao, Z., Xu, K., Xu, J., Tang, W., Wang, J. \& Song, E. (2011). Hepatitis B virus $X$ protein down-regulates expression of the miR-16 family in malignant hepatocytes in vitro. Br J Cancer 105:146-153.

Xu, J., Yun, X., Jiang, J., Wei, Y., Wu, Y., Zhang, W., Liu, Y., Wang, W., Wen,Y. \& Gu, J. (2010). Hepatitis B virus $X$ protein blunts senescence-like growth arrest of human hepatocellular carcinoma by reducing Notch1 cleavage. Hepatology 52:142-154.

Yang, L., Ma, Z., Wang, D., Zhao, W., Chen, L., Wang, G. (2010). MicroRNA-602 regulating tumor suppressive gene RASSF1A is overexpressed in hepatitis B virus-infected liver and hepatocellular carcinoma. Cancer Biol Ther 9:803-808.

Yang, S.Z., Zhang, L.D., Zhang, Y.. Xiong, Y.. Zhang, Y.J., Li, H.L., Li, X.W. \& Dong, J.H. (2009). HBx protein induces EMT through c-Src activation in SMMC-7721 hepatoma cell line. Biochem Biophys Res Commun 382:555-560.

Yarden, Y. \& Sliwkowski, M.X. (2001). Untangling the ErbB signaling network. Nat Rev Mol Cell Biol 2:127-137.

Yoo, Y.D., Ueda, H., Park, K., Flanders, K.C., Lee, Y.I., Jay, G. \& Kim, S.J. (1996). Regulation of transforming growth factor-beta 1 expression by the hepatitis $\mathrm{B}$ virus (HBV) $\mathrm{X}$ transactivator. Role in HBV pathogenesis. J Clin Invest 97:388-395.

Yoo, Y.G., Oh, S.H., Park, E.S., Cho, H., Lee, N., Park, H., Kim, D.K., Yu, D.Y,, Seong, J.K. \& Lee, M.O. (2003). Hepatitis B virus $X$ protein enhances transcriptional activity of hypoxia-inducible factor-1alpha through activation of mitogen-activated protein kinase pathway. J Biol Chem 278:39076-39084.

Yoon, H. \& Donahue, T.F. (1992). The suil suppressor locus in Saccharomyces cerevisiae encodes a translation factor that functions during tRNA(iMet) recognition of the start codon. Mol Cell Biol 12:248-260.

Zhang, Z., Sun, E., Ou, J.H. \& Liang, T.J. (2010). Inhibition of cellular proteasome activities mediates HBX-independent hepatitis B virus replication in vivo. J Virol 84:93269331.

Zhang, Z., Torii, N., Furusaka, A., Malayaman, N., Hu, Z. \& Liang, T.J. (2000). Structural and functional characterization of interaction between hepatitis $B$ virus $X$ protein and the proteasome complex. J Biol Chem 275:15157-15165.

Zhang Z. Torii N. Hu Z. Jacob J. Liang TJ. (2001). X-deficient woodchuck hepatitis virus mutants behave like attenuated viruses and induce protective immunity in vivo. $J$ Clin Invest 108:1523-1531. 
Zhang Z. Protzer U. Hu Z. Jacob J. Liang TJ. (2004). Inhibition of cellular proteasome activities enhances hepadnavirus replication in an HBX-dependent manner. J Virol 78:4566-4572.

Zheng, D.L., Zhang, L., Cheng, N., Xu, X., Deng, Q., Teng, X.M., Wang, K.S., Zhang, X., Huang, J. \& Han, Z.G. (2009). Epigenetic modification induced by hepatitis B virus $X$ protein via interaction with de novo DNA methyltransferase DNMT3A. J Hepatol 50:377-387.

Zoulim, F., Saputelli, J. \& Seeger, C. (1994). Woodchuck hepatitis virus X protein is required for viral infection in vivo. J Virol 68:2026-2030. 


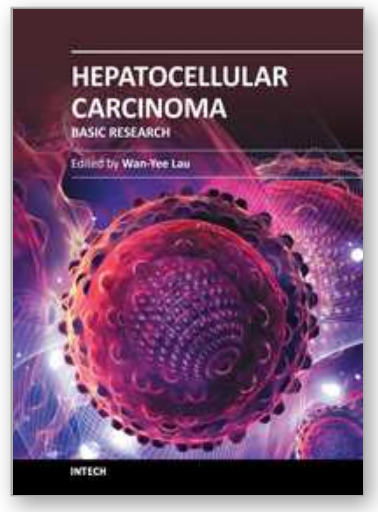

\author{
Hepatocellular Carcinoma - Basic Research \\ Edited by Dr. Joseph W.Y. Lau
}

ISBN 978-953-51-0023-2

Hard cover, 402 pages

Publisher InTech

Published online 10, February, 2012

Published in print edition February, 2012

Hepatocellular Carcinoma represents a leading cause of cancer death and a major health problem in developing countries where hepatitis $B$ infection is prevalent. It has also become increasingly important with the increase in hepatitis $C$ infection in developed countries. Knowledge of hepatocellular carcinoma has progressed rapidly. This book is a compendium of papers written by experts to present the most up-to-date knowledge on hepatocellular carcinoma. This book deals mainly with the basic research aspect of hepatocellular carcinoma. The book is divided into three sections: (I) Biomarkers / Therapeutic Target; (II) Carcinogenesis / Invasion / Metastasis; and (III) Detection / Prevention / Prevalence. There are 18 chapters in this book. This book is an important contribution to the basic research of hepatocellular carcinoma. The intended readers of this book are scientists and clinicians who are interested in research on hepatocellular carcinoma. Epidemiologists, pathologists, hospital administrators and drug manufacturers will also find this book useful.

\title{
How to reference
}

In order to correctly reference this scholarly work, feel free to copy and paste the following:

Mark A. Feitelson, Alla Arzumanyan, Tiffany Friedman, N. Lale Tufan, Zhaorui Lian, Marcia M. Clayton, Joyce Kang, Helena M. G. P. V. Reis, Jingbo Pan, Jie Liu, Patrick Arbuthnot and Michael Kew, (2012). Mechanisms of HBx Mediated Liver Cancer: Multiple Pathways and Opportunities, Hepatocellular Carcinoma - Basic Research, Dr. Joseph W.Y. Lau (Ed.), ISBN: 978-953-51-0023-2, InTech, Available from: http://www.intechopen.com/books/hepatocellular-carcinoma-basic-research/hepatitis-b-virus-andhepatocellular-carcinoma-

\section{INTECH}

open science | open minds

\section{InTech Europe}

University Campus STeP Ri

Slavka Krautzeka 83/A

51000 Rijeka, Croatia

Phone: +385 (51) 770447

Fax: +385 (51) 686166

www.intechopen.com

\author{
InTech China \\ Unit 405, Office Block, Hotel Equatorial Shanghai \\ No.65, Yan An Road (West), Shanghai, 200040, China \\ 中国上海市延安西路65号上海国际贵都大饭店办公楼405单元 \\ Phone: +86-21-62489820 \\ Fax: $+86-21-62489821$
}


(C) 2012 The Author(s). Licensee IntechOpen. This is an open access article distributed under the terms of the Creative Commons Attribution 3.0 License, which permits unrestricted use, distribution, and reproduction in any medium, provided the original work is properly cited. 